\title{
Do Parents Know Best?
}

\author{
John Eekelaar \\ Emeritus Fellow, Pembroke College, Oxford, UK \\ john.eekelaar@pmb.ox.ac.uk
}

\begin{abstract}
While Article 5 of the UN Convention on the Rights of the Child requires states to respect parents' responsibilities to provide 'appropriate' direction and guidance to their children, Article 18 also proclaims that 'the best interests of the child will be [the parents'] basic concern'. But how can this be done if, as is widely accepted, the "best interests" standard is too indeterminate safely to allow courts to substitute their assessment of children's interests for those of a child's parents? This reason for privatising such decisions has been reinforced by concerns over the extent of public expenditure on court involvement in and legal aid for such issues, with the possible result of withdrawal of the law from this process. This article argues that there are inherent risks in leaving the arrangements for children of separating parents entirely in the hands of the parents, and considers various ways in which such risks might be reduced.
\end{abstract}

\section{Keywords}

UNCRC Articles 6 and 18 - child arrangements - divorce and separation - best interests of the child - privatisation - de-legalisation

\section{$1 \quad$ Introduction}

While there is legitimate discussion about what direction and guidance which parents and some others are responsible to provide their children is 'appropriate' and 'consistent with [their] evolving capacities' in accordance with Article 5 of the UNCRC, Article 18 seems to establish an overall obligation that states shall 'use their best efforts' to ensure that, in doing that, 'the best interests of the child will be [the parents'] basic concern'. This obligation is inevitably somewhat imprecise. Tobin and Seow (2019) suggest it should be 
considered 'equivalent to the obligation to take all appropriate measures', and that 'the most that can be reasonably expected of states is that they undertake their best efforts.' This can perhaps be reasonably understood in the sense of "do their best to".

Within this framework, the question explored here is, outside cases of abuse and neglect, what would "doing their best" look like in circumstances where parents are separating? On one view the problem is resolved by not involving the courts, or perhaps even the law, at all, and leaving the problem to the parents to work out between themselves. Courts are usually obliged to apply the "best interests" principle, and of course this is mandated by Article 3 of the UNCRC. ${ }^{1}$ But, ironically, that could be the problem. Famously, Robert Mnookin (1975:260) commented:

Deciding what is best for a child poses a question no less ultimate than the purposes and values of life itself. Should the judge be primarily concerned with the child's happiness? Or with the child's spiritual and religious training? Should the judge be concerned with the economic 'productivity' of the child when he grows up?

These questions challenge the position that courts are best placed to make these decisions, or even whether it is appropriate at all that they do so. So Mnookin (1975: 266) concluded that, outside cases of abuse and neglect:

... there are affirmative justifications for making the family the presumptive locus of decision-making authority, particularly if there is no social consensus about what is best for children. Within the family, the child is more likely to have a voice in the decision, even if his wishes may not be determinative. Family members are more likely to have direct knowledge about a particular child. Affection for the child and mutual self-interest of family members are more likely to inform decisions.

However, somewhat reluctantly, Mnookin does not abandon the law (since, as he saw it, cases will continue to be decided by judges) but suggests three 'intermediate' rules through which the best interests test could be mediated:

First, custody should never be awarded to a claimant whose limitations or conduct would endanger the health of the child under the minimum

1 For further discussion of the relevance of context in the application of this principle, see Eekelaar (2015); Eekelaar and Tobin (2019). 
standards for child protection described above ... Second, the court should prefer a psychological parent (i.e., an adult who has a psychological relationship with the child from the child's perspective) over any claimant (including a natural parent) who, from the child's perspective, is not a psychological parent ...Third, subject to the two rules noted above, natural parents should be preferred over others (ibid: 282-3).

Many years later, Mnookin (2014) advocated a presumption that the child's time with each parent after separation should approximate the times spent with each parent when they were together.

Mnookin's suggestion that, given the nature of the judgments that must be made, the matter should (at least presumptively) be left to the parents, was enthusiastically taken up by Kimberly and Robert Emery (2014), eminent advocates of mediation in the United States. In an article entitled, "Who knows what is best for children? Honoring agreements and contracts between parents who live apart", they attribute the reluctance of the law to become involved in ongoing marital relationships to an assumption 'that the interests of married parents and children are aligned, except in cases of abuse or neglect' (ibid: 166) and argue that separated families are just another form of family, so the same assumption should apply to them. The "best interests" standard would remain, but courts would be explicitly required to accept what the parents agreed as satisfying that standard (except in cases of abuse and neglect) for, as they conclude in their article: 'Who knows what's best for children? In theory and in practice, the answer is their parents, whether married or living apart' (ibid: 176).

If that is so, what is there left for the state to do apart from trying to bring about agreement between the parents in ensuring that parents treat their children's interests as their basic concern?

\section{Privatisation and Liberalisation}

This perspective has been given added impetus by a general movement towards privatisation of the resolution of (private) family disputes. This is a rather different process from the one usually described as "liberalisation" (see Antokolskaia, 2016). Liberalisation involved bringing the written law into line with what was often collusion on a grand scale, where couples manipulated fault-based grounds in order to achieve consensual divorce, as was the case in France and Germany before reforms in 2005 and 1976 respectively, and in England and Wales before the reform of 1971, although in the case of England and 
Wales (and to a lesser extent, Germany), such manipulation continued after the reforms. In English law this was because divorce could be obtained relatively quickly under the reformed law provided one party did not oppose an allegation of adultery or of 'unreasonable behaviour', which did not necessarily imply fault (though it usually did) but did assume a judgment about whether that party's behaviour was such that it would be unreasonable to expect the other to live with him or her: what could be characterised as "judgemental divorce". ${ }^{2}$

Liberalisation resulted in making divorce available more easily, either by agreement subject to some waiting period, of varying lengths, ${ }^{3}$ or even without any waiting period, as in Sweden from 1973 if there were no minor children, or on the unilateral demand of one spouse after a short period of reflection, as also introduced by that Swedish law. This, of course, has strong elements of privatisation, but is not identical to it because some element of public involvement remained in the form of an order of a court or some administrative body, no matter how much this was a formality, and could also be present with respect to the arrangements regarding children, finances and property.

The movement towards privatisation in family law has been largely driven by concerns over its costs to the court system and legal aid budgets. (For examples of the extensive literature on this, see Eekelaar, 2011; Maclean et al. (eds.), 2015; Maclean and Eekelaar, 2019; Maclean and Dijksterhuis (eds.), 2019). This provided a powerful additional motivation for moving the resolution of family issues from the court system to the private arena. One of the most striking examples is the new divorce procedure introduced in France from 1 January $2017^{4}$ which allows parties (who must both be French nationals) to agree the divorce and its financial and other consequences (Ferrand, 2018; Bastard, 2019). This requires that in such cases, to become effective, the agreement must be filed with a notary public, who simply carries out a document check. It must have been signed by each party, assisted by a lawyer, after a short (twoweek) period of reflection. It is provided that the agreement must cover certain specified matters, which include whether compensatory payment should be made, and any division of property. Although not specifically mentioned, the agreement could cover matters concerning "parental responsibilities" (what would be called "child arrangements" in England and Wales). Any children must be informed, and given the opportunity to ask for the matter to go to a judge. If they do not, and these conditions are satisfied, the divorce becomes

2 See, e.g., Owens v. Owens [2018] U KSC 41.

3 As in many US states.

4 Law No. 2016-1547, 18 November 2016, Article 50, supplementing Code Civil, Article 229. 
effective without its submission to a court, and the agreement could be enforced according to the principles of contract law.

The nature and extent to which a process can be said to be "privatised" can take a number of forms. At one extreme, suppose that no recourse is provided for public resolution of these matters even where the parties disagree. This might be the case where, for example, a marriage or a parental relationship is not recognised, or access to adjudication or resolution mechanisms is denied to one party on the grounds of gender, or of religion, or is effectively impossible because of absence of financial or other support. In such cases the parties are abandoned to their own arrangements, if any. They may agree or they may not, but in either case, without any prospect of recourse to some form of adjudication, the result to be expected is that the more powerful prevails. It is probable that in about half of cases where married or long-term unmarried relationships break down in England, the parties wish to settle matters 'without outside help' (Barlow et al., 2017: 85-6).

But privatisation need not take such an extreme form. It may be mitigated, if, for example, the parties wish to take advantage of mechanisms provided by the state whereby agreements, if reached, can become enforceable in some way, thus promoting certainty over time. But this is still a strong form of privatisation, since the state gives its support to "private" arrangements, though the degree of its strength depends on the extent (if any) to which the state subjects such agreements to some form of scrutiny (the issue to be explored below). It is also affected by the nature of any assistance provided towards reaching agreement.

\section{$3 \quad$ Privatisation and De-legalisation}

There is a further complication. A distinction should be drawn between privatisation and de-legalisation. For example, in the new "privatised" French divorce process, described above, the law is nevertheless very much present. Indeed, lawyers welcomed the measure as each party must appoint a lawyer to take care of their interests; the agreement must contain a list of items specified by law as to be agreed on and the agreement must be checked by and filed with a notary public. Furthermore, each spouse may apply for free legal advice, and it has even been doubted whether the result will reduce costs to the parties or the state compared to judicial divorce (Ferrand (2018: 200)). In contrast, Jana Singer (2014) has argued, with respect to parenting disputes, that the shift away from adjudication to alternative dispute resolution (ADR) had undermined not only the place of lawyers but also of legal norms in the process. 'No longer', says 
Singer, 'is the question, "Which, among a predetermined set of custody outcomes, would be right or best for this family according to some external set of criteria"? Rather the expectation is that the process itself will generate the options and the disputants will evaluate those options according to their own interests and values' (Singer, 2014: 187; see also Murphy and Singer, 2015).

\section{$4 \quad$ Analysis}

\subsection{Viability of the "Best Interests" Standard}

All this raises a number of points that require unpacking. It will be noted that Mnookin's concerns over the forward-looking and speculative nature of the best interests standard did not lead him to reject legal norms entirely. Indeed, he suggested, albeit reluctantly, that some types of legal presumption might be necessary simply in order to make decisions practicable. Singer, on the other hand, as noted above, argued that the very impracticality of that standard for traditional adjudication had led to greater use of ADR, which, in turn, weakened the relevance of legal norms.

It is possible that Mnookin's concerns about the best interests standard were exaggerated, or even misplaced. It is, of course, usually true that the longerterm outcomes of such decisions are impossible to know. That is also true for most decisions people make in their lives, whether for themselves (such as who to date, or to marry, what to study, what job to take, and so on) and, if they are parents, those touching their children (where to live, what interests to encourage, what books to read, what religion (if any) to follow). But that does not mean that rational decisions cannot be made regarding what is the best thing to do in such situations. They will, of course, reflect broad social values, which may be contested, but decisions can be made, based on the evidence available. There may be more than one option, between which reasonable choices may be made. In the case of children, this requires a conscious effort to focus on the child concerned, hearing the child's views and, while allowing for competence factors and not neglecting other interests completely, to seek an outcome most likely to enable the child to achieve what is of value to the child from the perspective of the child as a potential independent adult (Eekelaar (2017: $55^{-5}$, $59,131-132)$ ).

If we can accept that the best interests standard can be used in this way in deciding matters concerning children, the question remains as to where this decision is best made. Given the features of such decisions identified by Mnookin, it is hardly possible to compare empirically the long-term outcomes for children of decisions taken by their parents and those taken by others, 
including courts. In considering this matter, therefore, it is necessary to take into account the likely presence of factors that could undermine the quality of the decision from the child's perspective. In this respect, we need to compare the situations where parents, living together with the children, are not contemplating separation, and where they have separated, or are in the process of doing so.

The two situations share one important feature: the parents' power to affect the children's lives. That should put us on notice that there is an inherent risk of various forms of misuse of such power. However, there is a significant difference between the state imposing norms between people in ongoing intimate relationships, and regulating matters between them if they separate. In the former case, couples are engaged in a significant joint life project, involving the nature of intimacy, and the development of love and support in facing the joys, sorrows and difficulties of life. On a broader, social, perspective they are also involved in the inter-generational transmission of cultural or social values. In liberal societies, this ongoing joint project can best be achieved if the state respects the couple's own way of confronting the personal issues that might arise between them in providing the guidance required of them by Article 5, while providing them with advice and support at the same time. Who can say whether, in some objective sense, this is best for children? What could be said, however, is that, subject to the very important red lines which allow the welfare authorities to assume parental powers with respect to the child who has suffered, or is at risk of, significant harm, or where a court is required to resolve disputes over important matters, such as between the child's parents and medical personnel over the provision of treatment for the child, ${ }^{5}$ when the court will act on its own judgment concerning the child's best interests, or over educational issues, where the state's interests in the values of society as a whole are implicated, in liberal societies, it is 'best that' children are brought up in this way. By allowing this the state is 'doing its best' in accordance with Article 18.

The situation is very different if the parents separate. The joint project has failed between them, and made considerably more difficult with regard to the children. Parents in an ongoing relationship, living with their children, may have their differences over some matters of upbringing, but they seldom go to the very nature of the relationship between the child and one or both of the parents as is potentially the case when parents separate. Importantly, the parents' own interests are likely to diverge more sharply after separation which

5 See Yates and another v. Great Ormond Street Hospital [2017] EWCA Civ. 410; King's College Hospital NHS Foundation Trust v. Takesha Thomas, Laure Haastrup and Isaiah Haastrup [2018] EWHC 127. 
could either divert attention from the children's interests, or colour the assessment of those interests by the strongly competing interests of the parents. And there is another difference which is present in many (though by no means all) cases where parents separate: that is, that the family re-organisation and legal procedures that sometimes accompany it provide a point of entry whereby external agencies acquire the opportunity to obtain information about, and influence, the position of the children.

\subsection{Is Agreement Enough?}

But, it may be said, it is still best, despite those tensions between separating parents, to seek a solution by way of agreement between them. The evidence is clear that conflict between the parents in itself damages the well-being of the children involved (Lamb, 2007: 19; Shaffer, 2007; Fehlberg et al., 2015: 189), even if the arrangement has other benefits for the child, for example, by maintaining relationships with both parents (Nielsen, 2018), which indicates that the fact that the parents agree on post-separation arrangements regarding the children is in itself beneficial for the children. It might be concluded that the objective of resolution processes should therefore be to achieve such agreement, rather than to focus on the actual outcome for the child.

This is an important point. However, the fact that parties may have agreed does not necessarily mean there is no conflict, either because the agreement was reached reluctantly, or contains elements likely to induce conflicts later. But even if there are no conflicts, what about the substance? An agreed solution may usually be better than disagreement, but that does not mean that the factors mentioned above that may be present between separating couples may not have made it less beneficial, or even less safe, for the child than a different solution could have achieved. Evidence from observations of mediation suggests that even though mediators may refer to the desirability of putting the children's interests first, the degree to which they balance that objective with achieving an outcome on which the parents agree seems to vary (Barlow et al., 2017: 201-202; Harada, 2019; Maclean and Eekelaar, 2016: 87-91; 122-129; Ryrstedt, 2012).

In 1958, advantage was taken in England and Wales, and Scotland, of the fact that divorce could provide a "point of entry" for examination of the position of the children. It was laid down that, before a divorce could be granted, any arrangements for children had to be submitted to the court for certification that they were 'satisfactory or the best that could be devised in the circumstances'. This was confirmed in section 41 of the Matrimonial Causes Act 1973. It was

6 Matrimonial Proceedings (Children) Act 1958. 
applied by means of a private meeting between the judge and the parties (a 'children's appointment'), and this took place even after undefended cases involving children became subject in 1977 to the 'Special Procedure', which from 1973 had allowed divorce to be granted on the basis of submitted papers alone in undefended cases where no children were involved. But, somewhat oddly, the judge at the children's appointment was not supposed to consider any agreements over finances or property: that was a matter for the registrar when deciding whether to incorporate them into a Consent Order, where the welfare of the child was not given such prominence (Eekelaar, 1985).

The Matrimonial Causes Procedure Committee (Booth Committee) of 1985 (which anticipated recent moves towards allowing joint applications for divorce) sought to take this further, in an echo of much earlier debates over the role of the courts in private family disputes that include the (unsuccessful) attempts in the 1930s of the magistrate, Claud Mullins, and immediately postwar schemes, to enhance the welfare functions of the family courts. (See detailed discussions by Cretney (1998: chs. 5 and 6) and Murch (2018)). However, those earlier initiatives were primarily aimed at saving marriages. In contrast, the Booth Committee sought to enhance agreement, that is, conciliation rather than reconciliation, a shift also evident in the practice of the court welfare service (Dingwall and Eekelaar (eds.), 1988: ch. 1 and ch. 4 (by Adrian James)). The Committee distinguished between divorce cases involving children and those that did not and proposed that in all cases involving children, defended or otherwise, there should be an initial, informal, hearing before a registrar with the objective of promoting and giving effect to agreements. Where agreement had been reached, the function would primarily be supervisory, combining the 'children's appointment' with giving first consideration to the welfare of any children in any financial and property orders agreed. ${ }^{7}$ If so satisfied, the Consent Order could be made solely on the basis of the written documents. ${ }^{8}$ At the same time it seemed that the role of the court as scrutineer of arrangements on behalf of the child might be enhanced. Section 3 of the Matrimonial and Family Proceedings Act 1984 required courts in England and Wales, when

7 With respect to financial and property orders, Sir Roualeyn Cumming-Bruce remarked: ' ... if it had been intended to be paramount, overriding all other considerations pointing to a just result, Parliament would have said so. It has not. So I construe the section in requiring the court to consider all the circumstances, including those set out in subsection 2, always bearing in mind the important consideration of the welfare of the children, and then try to attain a financial result which is just as between husband and wife: Suter v. Suter \& Jones [1987] Fam 111,123 .

8 Matrimonial and Financial Proceedings Act 1984, s. 7, inserting section 33A into the Matrimonial Causes Act 1973. See Eekelaar (1986). 
considering the matters it was to take into account when making financial and property orders, to give 'first consideration' to the 'welfare while a minor of any child of the family who has not attained the age of eighteen'.

However, the future went in the opposite direction. Already in 1977, research in England and Wales and in Scotland had demonstrated that almost nothing was achieved by the section 41 children's appointments, which consisted in a brief interview of the parents by the judge. Even where the process led to an investigation, it resulted in change in only o.6 per cent of cases in England and Wales and only one in the sample of 203 cases in Scotland (where the process also applied) (Eekelaar and Clive, 1977). A devastating study carried out between May 1979 and June 1980 of these appointments in five courts in England revealed not only the stress they caused parents, but their overall failure to achieve any benefit (Davis, MacLeod and Murch (1983)). It seemed that even if the investigation brought to light a less than satisfactory situation, there was little or nothing which the court could do about it. In general, the parties made their own arrangements and the court accepted them. So, far from taking up the Booth Committee's suggestion about informal meetings, Guidance accompanying the Bill that was to become the Children Act 1989 observed that, 'children are generally best looked after within their families', which Lady Hale (2000:463) defended on the ground that 'any civilised society has to start from the proposition that children are best brought up in their own families: it is the bedrock of society that children belong in families and not to the state.' In 1989 the children's appointment system was abolished and the need for the court to certify, prior to granting divorce, that the child arrangements were 'satisfactory or the best that could be devised in the circumstances' was reduced to a duty to consider only whether the proposed arrangements for children called for a court order. ${ }^{9}$ After further research showed how little time judges took doing this (about five minutes) and lack of clarity about how to apply it (Douglas, Murch, Scanlan and Perry (2000)), in 2014 this too was removed. ${ }^{10}$

So as a result it is now only if parties, having reached agreement, are seeking a Consent Order implementing that agreement that the position of the children will be monitored. This is because section 1 of the Children Act 1989 requires a court, when determining any question with respect to the upbringing of a child (essentially, 'child arrangements') to make the child's welfare its 'paramount consideration'. Making a Consent Order containing child arrangements would seem to be a 'determination' under section 1 . There is no requirement that parties do seek such an order, but they may wish to do so because this

$9 \quad$ Children Act 1989, Sch. 12, para. 31.

10 Children and Families Act 2014, s. 17. 
makes anything they have agreed (if appropriate) enforceable as an order of court. Similarly, if financial or property matters are included in the order sought, the court must give 'first consideration' to the welfare of children as required by section 25 of the Matrimonial Causes Act.

How is this done? As regards financial and property orders, a perusal of information given on websites regarding preparing Consent Orders on these matters shows they often pay little or no attention to the effect on children. For example:

Couples often assume that just because they have agreed a financial settlement that the Judge will grant them their order. However, this is a dangerous attitude to have as the Judge will only grant the order if he or she feels that the order is fair to both parties No, you do not need to physically attend a court to file a consent order; it is all done by post (Divorce Online).11

The Court does not have to agree to the Consent Order, regardless of the fact that it has already been agreed by the couple. The Court will use their discretion to determine whether the agreement between the couple is fair and whether each person can actually afford to fulfil their side of the agreement (Co-op Legal Services). ${ }^{12}$

The government site, "Get a Divorce: Step By Step", makes no mention of children when addressing money and property issues. ${ }^{13}$ But AdviceNow (2019: 11), the website hosted by the charity, Law for Life, paints a very different picture, setting out the principles in this way:

We explain these basic principles here: The welfare of any child of the family under 18 years old. This is a very important factor and will be the first thing a court considers. In many cases, it can mean that most, maybe all, of your joint resources should go towards providing a home for your children. Typically the children will live with the person mostly responsible for their day to day care. This is why it is common to come across situations where the person mainly looking after the children stays with them in the family home. Before you discuss it, think about what you want to agree. What is best for any children you may have?

\footnotetext{
11 https://www.divorce-online.co.uk/help-and-advice/consent-order-information/.

12 https://www.co-oplegalservices.co.uk/media-centre/articles-sep-dec-2017/what-is-a -consent-order-in-a-divorce/.

13 https://www.gov.uk/money-property-when-relationship-ends/mediation.
} 
In 2014, the Law Commission commented that:

If there are children who must be cared for and limited resources available, the parent who primarily cares for those children should be securely housed in priority to the other parent. Preferably she or he and the children should remain in the family home after divorce if they wish and if that will not prevent the other parent from being able to be housed. If such an outcome would be unfair in terms of the capital split then the other parent could retain an interest in that property, under a trust or charge, that can be realised at a later date, usually on the youngest child leaving secondary or tertiary education. Alternatively, it may be that both parents can reasonably afford to retain or buy a property, perhaps by downsizing (Law Commission, 2014: [3.97]).

As regards child arrangements, the situation has been significantly affected by the introduction of the Children and Family Courts Advice and Support Service (Cafcass) in 2001. This is an independent body charged with the duty, 'in respect of family proceedings in which the welfare of children ... is or may be in question' to (a) safeguard and promote the welfare of the children, (b) give advice to any court about any application made to it in such proceedings, (c) make provision for the children to be represented in such proceedings, and (d) provide information, advice and other support for the children and their families. ${ }^{14}$ It was designed to integrate into one body similar services that were previously dispersed across the probation service, independent and local authority social workers acting as guardians ad litem and reporting officers and the Official Solicitor. The principal role of the Cafcass's Children and Family Reporter in private law proceedings has been described as being:

... to investigate and report on issues concerning the welfare of children involved in disputes about residence and contact, at the request of the court. The role has traditionally been described as "acting as the eyes and ears of the Court." The Children and Family Reporter may also assist parents to resolve any outstanding areas of disagreement, if this is possible during the course of their enquiries (House of Commons Select Committee on the Lord Chancellor's Department, 2003: ch. 2, [9]).

In the divorce context, the establishment of Cafcass seemed to provide an opportunity for intervention and support to occur at an early stage, with a strong 
focus on the children's welfare, making it more likely that agreements reached would reflect the children's interests. However, this was impeded by initial problems over management and personnel, followed by government austerity policies. Reviewing the situation in 2015, a Report from Relate (Marjoribanks, 2015) referred to the Cafcass website which 'provides information for children whose parents are involved in court proceedings', its piloting of 'SPIP Plus' 15 in some areas, which adds an additional hour where both parents attend together with a mediator, and its call centre including a free helpline in which 'callers speak to an experienced professional who talks through the difficulties with them, identifies needs and assess what support may be helpful, and offers impartial information and guidance on the most appropriate dispute resolution pathways'. Unsurprisingly, Murch (2018: 217) has described the opportunity as being 'largely undeveloped'.

With respect to the assistance that Cafcass gives to the court in cases where agreement has been reached, section 9, paragraph 41 of the Family Court Bench Book, published by the Judicial College in 2018, summarises the position thus:

In all cases, it is for the court to decide if an order accords with the welfare of the child. Any proposed order, whether to be made by agreement or not, must be scrutinised by the court. The court must not make a consent order, or give permission for an application to be withdrawn, unless the parties are present in court, all initial safeguarding checks have been obtained by the court and an officer of Cafcass/CAFCASs Cymru has spoken to the parties separately, except where it is satisfied that there is no risk of harm to the child and/or the other parent in doing so. The court has to consider all the evidence and information available to help it decide if there is any risk of harm to the child.

However, despite the reference to the need for the parties to be present in court, the government digital "tool" advising people seeking a Consent Order regarding child arrangements ${ }^{16}$ states that the parents must send in the appropriate documents, including a draft Consent Order, and adds:

There's usually no court hearing. A judge will approve your Consent Order to make it legally binding if they think you've made decisions in your children's interest. If the judge does not think your consent order is

\footnotetext{
15 Separated Parents Information Programme (see further below).

16 https://www.gov.uk/looking-after-children-divorce/if-you-agree.
} 
in your children's interest they can: change your consent order or make a different court order to decide what's best for your children.

It is also interesting that the limited bases upon which Consent Orders can be set aside seem to be focused on matters, such as non-disclosure, that affect the fairness of holding one of the parties to the agreement, ${ }^{17}$ and not the welfare of the children.

\section{The Limits of Law}

But the parents may not have brought the child arrangements, or even the financial or property issues, before the court at all: they may have just settled them between themselves, with or without professional (or other) help. There could be a case for restoring the requirement that divorcing parties set out their arrangements for the children as a condition for obtaining a decree, whether or not they desire a Consent Order. Something like this is required in a number of jurisdictions (Scherpe and Trinder, 2019: 15). It could concentrate the parents' minds on the issue, and widen the possible points of entry if they reveal something truly unusual. The downside is that it could create an opportunity for a party to obstruct the divorce process itself, and in its recent review of divorce law, the government has not proposed it, commenting that in any case such an agreement presents only a 'snapshot in time and not reflecting the changing needs of children over time' (Ministry of Justice, 2019: 34). But Australian courts have said this is an important feature of their divorce process (Fehlberg et al., 2015: 111-2), and in some jurisdictions officials (sometimes) play an important role. Antokolskaia (2016: $76-7$ ) gives examples of Portugal and Iceland.

What then should be the role of the courts in this matter? The possibilities will strongly reflect the legal and administrative "culture' of respective jurisdictions. For England and Wales, Douglas et al. (2000) have argued that courts should play a 'supportive' role, channelling people to agencies that could provide appropriate guidance, and in its recent review of the divorce law, the UK government stated that it would 'explore options for information sharing and signposting to encourage divorcing parents to make informal child-centred arrangements during the legal process of divorce, where making such arrangements is safe and appropriate' (Ministry of Justice, 2019: 34). At present courts may recommend, or indeed order, parents to attend special classes to guide

17 Liveseyv.Jenkins [1985] FLR 813; Sharland v. Sharland [2015] U KSC 60. 
them how best to cater for their children's interests after separation. The success of these is hard to evaluate. A 2011 study of the Parenting Information Programme (PIP) in England and Wales (Trinder et al., 2011) concluded that attending the programme (a group session) had no effect on parental relationships, though it did result in a higher rate of contact between the child and the non-resident parent, though there was no evidence that this was seen as being in the best interests of the child. A later study by the same researchers of an enhanced programme (now involving an additional joint session by the couple with an adviser) showed no change in effect on parental relationships, but a modest improvement in agreements reached, though again, whether these enhanced the interests of children was not known (Trinder et al., 2014). But such opportunities usually occur only if a dispute has come to court, and the conflict may have deepened.

The key seems to be the provision of good advice at an early stage. After all, independent legal advice is required by many jurisdictions for the enforceability of pre-marital agreements (Scherpe (ed.), 2012: 491-495). If legal oversight is deemed necessary to safeguard vulnerable adults in regard to their property interests, why should not something similar be required in the case of arrangements for children? The new French consensual divorce process mentioned earlier rests heavily on the requirement that each party must be advised by a lawyer, and the law mandates various matters to be covered in the agreement (Ferrand, 2018); Bastard, 2019). The lawyers should be well acquainted with the relevant norms, and English courts have tended to place great reliance on the presence of legal advice as an important means of safeguarding the interests of parties entering such agreements. But each party will be the client of each lawyer, and it may be hard for the lawyers not to put the satisfaction of their clients first, even if this may not be best for the children.

It might be easier for a lawyer to act more objectively with regard to the children's interests if the same lawyer was advising the clients jointly. There is resistance to this among solicitors, who are required not to act, 'if there is a client conflict, or a significant risk of a client conflict'. But there is an exception if the clients have a substantially common interest in relation to a matter or a particular aspect of it', the clients have given informed consent to it, and if the solicitor thinks this is in their best interests and the benefits outweigh the risks. The substantial common interest could be the duty to make their children's interests their 'basic concern'. Such a process, which Mavis Maclean and I have proposed should be allowed to be undertaken by lawyers with mediation training in what we called 'legally-assisted family mediation' (Maclean and Eekelaar, 2016:129-137), places the lawyer-mediator in an advisory role that not only facilitates agreement, but one performed by someone with knowledge of the 
relevant legal norms, with their focus on the child's interests, and also the best legal means of achieving this (Maclean and Eekelaar, 2019: 17-18).

But it is arguable that the advice need not be from a lawyer: indeed, expertise other than legal may be equally, if not more, important. Already, agreed child arrangements are referred to Cafcass for a safeguarding check. Might it be possible to involve Cafcass at an even earlier stage, perhaps by requiring parties to have submitted their agreed proposals to a Cafcass officer before applying to the court, and even giving Cafcass officers power to refer parties to counselling or other services, as proposed by Murch (2018: 332)? In 2019 a Working Group of professionals reporting to the President of the Family Division on the way the Child Arrangements Programme (CAP $)^{18}$ was operating, expressed its belief that such issues are best dealt with outside the court, and that 'a national non-court dispute resolution ("Family Solutions") service should be actively considered' (Private Law Working Group, 2019: [9]). However, it thought that, 'radical reform of the way society deals with children disputes following family breakdown away from the court would only be likely to be effective if supported by a public education campaign; cultural change would be necessary in order to deliver it'. In Denmark in 2019 a new administrative authority, the Agency for Family Law (Familieretshuset), was established which parents must initially approach before accessing the court. The Agency will perform a triage function and can provide measures such as counselling and other assistance, with the primary goal of protecting the children's interests. The Agency can also make final decisions in some matters, which are appealable to the court. Might the role of Cafcass be developed along these lines (Singer, 2020)?

But, as in the case of ongoing families, there are limits to the degree of proactive intrusion liberal societies can exercise with regard to family life. This has been called the "liberal compromise", a feature of which is the so-called "rule of optimism" that parents generally treat their children as well as they can. This does not imply an assumption that professionals coming into contact with families, whether ongoing or separating, will be disposed always to believe that is happening in each case. Far less is it an application of the view of Kimberly and Robert Emery that as a matter of fact, parents always know what is best for their children. Rather, as Robert Dingwall has put it in the context of child protection services, the rule 'is a dimension of the organizational culture of (those services) which is founded on the deep ambivalence that we feel in a liberal society about state intervention in families' (Dingwall et al., 1995: 247).

18 The CAP sets out practices to be followed when a dispute arises between separated parents and/or families about arrangements concerning children: Family Proceedings Rules 2010, Practice Direction 12B. 
We therefore should perhaps recognise that the claim that "parents know best" is not so much a statement that this is always, or even mainly, the case, but that in 'doing their best' under Article 18 to ensure that parents do treat their children's best interests as their basic concern when fulfilling their Article 5 duties, the best interests principle must be tempered by the need for constraints on institutional intrusion into the arrangements parents make for their children.

\section{References}

AdviceNow, A survival guide to: Sorting out your finances when you get divorced, 2019. Antokolskaia, M., "Divorce law in a European perspective" in J. M. Scherpe (ed.), European Family Law, Vol. III, Family Law in a European Perspective (Cheltenham: Edward Elgar, 2016).

Barlow, A., Hunter, R., Smithson, J. and Ewing, J., Mapping Paths to Family Justice: Resolving Family Disputes in Neoliberal Times (London: Palgrave Socio-Legal Studies, 2017).

Bastard, B., "Family Justice in France: Two Dimensions of 'Digitisation", in M. Maclean and B. Dijksterhuis (eds.), Digital Family Justice:from Alternative Dispute Resolution to Online Dispute Resolution? (Oxford: Hart Publishing, 2019).

Cretney, S. M., Law, Law Reform and the Family (Oxford: Oxford University Press, 1998). Davis, G., MacLeod, A. and Murch, M., "Undefended Divorces: Should Section 41 of the Matrimonial Causes Act 1973 be repealed?", Modern Law Review, 1983 (46), 121-46.

Dingwall, R. and Eekelaar, J., Divorce, Mediation and the Legal Process (Oxford: Clarendon Press, 1988).

Dingwall, R., Eekelaar, J. and Murray, T., The Protection of Children (2nd edn., Aldershot: Avebury, 1995).

Douglas, G., Murch, M., Scanlan, L. and Perry, A., "Safeguarding Children's Welfare in Non-Contentious Divorce: Towards a New Conception of the Legal Process?", The Modern Law Review 2000 (63), 177-96.

Eekelaar, J., "Consent Orders - in Whose Interests?", Law Quarterly Review 1985 (101), $318-22$.

Eekelaar, J., "Divorce English Style - A New Way Forward?", Journal of Social Welfare Law 1986, 226-36.

Eekelaar, J., "Not of the First Importance': Family Justice under Threat", Journal of Social Welfare and Family Law 2011 (33), 311-317.

Eekelaar, J., Family Law and Personal Life (2nd edn., Oxford: Oxford University Press, 2017).

Eekelaar, J., "The role of the best interests principle in decisions affecting children and decisions about children", International Journal of Children's Rights 2015 (23), 3-26. 
Eekelaar, J. and Tobin, J., "Article 3: The Best Interests of the Child" in J. Tobin (ed.), The UN Convention on the Rights of the Child: A Commentary (Oxford: Oxford University Press, 2019).

Eekelaar, J. and Clive, E., Custody after Divorce (Oxford: SSRC Centre for Socio-Legal Studies, 1977).

Emery, K. C. and Emery, R. E., "Who knows what is best for children? Honoring agreements and contracts between parents who live apart", Law and Contemporary Problems 2014 (77), 151-176.

Fehlberg, B., Kaspiew, R., Millbank, J., Kelly, F. and Behrens, J., Australian Family Law: The Contemporary Context (2nd edn.), Melbourne: Oxford University Press, 2015).

Ferrand, F., "Non-Judicial Divorce in France: Progress or a Mess?", in G. Douglas, M. Murch and V. Stephens (eds.), International and National Perspectives on Child and Family Law: Essays in Honour of Nigel Lowe (Cambridge: Intersentia, 2018).

Hale, B., "In Defence of the Children Act", Archives of Disease in Childhood 2000 (83) $463-6$.

Harada, E., "Family Reorganization in the Japanese Family Conciliation System: Resolving Divorce Disputes involving Minor Children", International Journal of Law, Policy and the Family 2019 (33(1)), 75-103.

House of Commons Select Committee on the Lord Chancellor's Department, Third Report (Session 2002-3).

Judicial College, Family Court Bench Book, 2019.

Lamb, M. E., "Parent-child contact in Separating Families" in M. Maclean (ed.), Parenting after Partnering: Containing Conflict after Separation (Oxford: Hart Publishing, 2007).

Law Commission, Matrimonial Property: Needs and Agreements (Law Com. No. 343, 2014).

Maclean, M., Eekelaar, J. and Bastard, B. (eds.), Delivering Family Justice in the Century 21st(Oxford: Hart Publishing, 2015).

Maclean, M. and Eekelaar, J., Lawyers and Mediators: The Brave New World of Services for Separating Families (Oxford: Hart Publishing, 2016).

Maclean, M. and Eekelaar, J., After the Act: Access to Family Justice after LASPO (Oxford: Hart Publishing, 2019).

Maclean, M. and Dijksterhuis, B. (eds.), Digital Family Justice: from Alternative Dispute Resolution to Online Dispute Resolution? (Oxford: Hart Publishing, 2019).

Marjoribanks, D., Breaking up is hard to do: Assisting families to navigate family relationship support before, during and after separation (Relate, 2015).

Ministry of Justice, Reducing family conflict: Government response to the consultation on reform of the legal requirements for divorce (Ministry of Justice, CP 59, 2019).

Mnookin, R. H., "Child Custody Adjudication: Judicial Functions in the Face of Indeterminacy", Law and Contemporary Problems 1975 (39), 226-293. 
Mnookin, R. H., “Child Custody Revisited”, Law and Contemporary Problems 2014 (77), 249-270.

Murch, M., Supporting Children when Parents Separate: embedding a crisis intervention approach within family justice, education and mental health policy (Bristol: Policy Press, 2018).

Murphy, J. C. and Singer, J. B., Divorced from Reality: Rethinking Family Dispute Resolution (New York: New York University Press, 2015).

Nielsen, L., "Joint Versus Sole Physical Custody: Children's Outcomes Independent of Parent-Child Relationships, Income, and Conflict in 60 Studies", Journal of Divorce \& Remarriage, 2018 DOI: 10.1080/10502556.2018.1454204.

Private Law Working Group, A review of the child arrangements programme (CAP) [PD12B FPR 2010]: Report to the President of the Family Division, 2019.

Ryrstedt, E., "Mediation regarding children - is the Result always in the Best Interests of the Child? A View from Sweden", International Journal of Law, Policy and the Family 2012 (26), 220-241.

Scherpe, J. and Trinder, L., Reforming the Ground for Divorce: Experiences from other Jurisdictions (London: Nuffield Foundation, 2019).

Scherpe, J. M. (ed.), Marital Agreements and Private Autonomy (Oxford: Hart Publishing, 2012).

Shaffer, M., "Joint Custody, Parental Conflict and Children's Adjustment to Divorce: What the Social Science Literature does and does not tell us", Canadian Family Law Quarterly 2007 (26), 286.

Singer, A., "Parenting issues after separation: a Scandinavian perspective" in J. Eekelaar and R. George (eds.), Routledge Handbook of Family Law and Policy (2nd edn. Abingdon: Routledge, 2020).

Singer, J. B., "Bargaining in the Shadow of the Best-Interests Standard: the Close Connection between Substance and Process in resolving Divorce-related Parenting Disputes", Law and Contemporary Problems 2014 (77), 177-194.

Tobin, J. and Seow, F., 'Article 18: Parental responsibilities and State Assistance' in Tobin J. (ed.), The UN Convention on the Rights of the Child: A Commentary (Oxford: Oxford University Press, 2019).

Trinder, L., Bryson, C., Coleman, L., Houlston, C., Purdon, S., Reibstein, J., Smith L. and Stoilova, M., Building Bridges? An Evaluation of the Costs an Effectiveness of the Parenting Information Programme (PIP) (London: Department for Education, DFE RR140, 2011).

Trinder, L., Bryson, C., Coleman, L., Houlston, C., Purdon, S., Reibstein, J., Smith, L. and Stoilova, M., Evaluation of the SPIP Plus: (sPIP Plus) Project (London: Department for Education, 2014). 